ISSN 1392-3196 / e-ISSN 2335-8947

Zemdirbyste-Agriculture, vol. 108, No. 4 (2021), p. 297-302

DOI 10.13080/z-a.2021.108.038

\title{
Botrytis four species are associated with chocolate spot disease of faba bean in Latvia
}

\author{
Biruta BANKINA ${ }^{1}$, Frederick L. STODDARD ${ }^{2}$, Jānis KAN̦EPS ${ }^{1}$, \\ Elina BRAUNA-MORŽEVSKA ${ }^{1}$, Gunita BIMŠTEINE ${ }^{1}$, Ingrīda NEUSA-LUCA ${ }^{1}$, \\ Ance ROGA ${ }^{3}$, Dāvids FRIDMANIS ${ }^{3}$ \\ ${ }^{1}$ Latvia University of Life Sciences and Technologies, Institute of Soil and Plant Sciences \\ Lielā 2, Jelgava, Latvia \\ E-mail: biruta.bankina@1lu.lv \\ ${ }^{2}$ University of Helsinki, Department of Agricultural Sciences \\ Latokartanonkaari 5-7, Finland \\ ${ }^{3}$ Latvian Biomedical Research and Study Centre \\ Rātsupītes 1, Rīga, Latvia
}

\begin{abstract}
Faba bean (Vicia faba L.) is gaining importance as a crop in northern Europe. In this region, the most important disease of faba bean is chocolate spot disease, attributed to the pathogen Botrytis fabae. However, other Botrytis species have been found to contribute to the disease. Hence, it was decided to isolate fungi from faba bean plants showing symptoms of chocolate spot disease in Latvia, identify the Botrytis species using the DNA sequences of three definitive genes, evaluate the morphological diversity of the isolates in vitro and, finally, to determine the pathogenicity of the isolates in a detached-leaf test. In addition to B. fabae, B. cinerea, B. pseudocinerea and B. fabiopsis were all identified. Phylogenetic analysis of the DNA sequences put all the obtained 44 isolates unequivocally into clusters with known examples of each species. Every species showed wide diversity in its in vitro colour, texture and growing pattern of mycelium, production of sclerotia and pigmentation of the growing medium with much overlap between species showing that this method is not adequate for species discrimination. $B$. fabae produced the largest lesions on infected leaves, followed closely by $B$. pseudocinerea and $B$. cinerea, while $B$. fabiopsis produced much smaller lesions.

The results show that chocolate spot disease of faba bean is attributable to Botrytis four species in northern Europe. This knowledge needs to be considered when controlling the disease by genetic or agronomic means.
\end{abstract}

Key words: Botrytis fabae, Botrytis cinerea, Botrytis pseudocinerea, Botrytis fabiopsis, phylogenetic analysis, morphological traits.

\section{Introduction}

In the European continent, areas sown to grain legumes have more than doubled between 2008 and 2019, and the increase in faba bean (Vicia faba L.) areas has been nearly three-fold (FAOSTAT, http://www. fao.org/faostat/en/\#data/QC). In the Nordic and Baltic countries, faba bean area increased from 10000 ha in 2008 to 150000 ha in 2019 (Eurostat, 2021). Therefore, the potential importance of faba bean leaf diseases has increased in parallel, and new pathogens have come to light (Bankina et al., 2021). Chocolate spot disease is one of the most important diseases of faba bean throughout the world (Stoddard et al., 2010). The disease's typical symptoms are small, chocolate-coloured spots scattered over the plant's lower leaves, usually starting around the time of onset of flowering. In moist conditions, flowers and young pods rot, and the disease may enter an aggressive phase killing the entire plant.

Because of the risk of high yield losses caused by this disease and the availability of sequencing techniques to identify organisms to the species level, in several countries investigations into the causal organisms have been initiated. B. fabae is viewed as the primary causal agent of chocolate spot disease. Several reports (Harrison, 1988; Coca-Morante, Mamani-Álvarez, 2012; Bilkiss et al., 2019) have mentioned B. cinerea as a pathogen of faba bean either separately or within a complex with $B$. fabae.

Zhang et al. (2010) identified and described the third species of Botrytis from faba bean in China $B$. fabiopsis. This species causes the same symptoms on faba bean as $B$. fabae and may be present in a complex with it and $B$. cinerea. These findings were supported by subsequent research (Fan et al., 2015; Elad et al., 2016). B. fabiopsis has been found in Latvia on faba bean (Brauna-Morževska et al., 2019). DNA analysis showed that $B$. cinerea comprised two distinct populations leading to the separation of $B$. pseudocinerea, which is similar in morphology but genetically distinct from $B$. cinerea

Please use the following format when citing the article:

Bankina B., Stoddard F. L., Kaṇeps J., Brauna-Morževska E., Bimšteine G., Neusa-Luca I., Roga A., Fridmanis D. 2021. Botrytis four species are associated with chocolate spot disease of faba bean in Latvia. Zemdirbyste-Agriculture, 108 (4): $297-302$. DOI 10.13080/z-a.2021.108.038 
(Plesken et al., 2015). Thus, at least four species of Botrytis have been associated with the chocolate spot disease of faba bean leading to hypothesize that the causal agents of a chocolate spot on faba bean in northern Europe might be more complex than the traditional view (Brauna-Morževska et al., 2019).

High phenotypic and genetic diversity exists within and between Botrytis species. Articles on the same species describe quite different morphologies, and there is considerable overlap between species (Zhang et al., 2010; Acosta Morel et al., 2019). In addition, there is a wide variation within individual Botrytis species in virulence against one given host plant, optimum growing conditions and resistance to fungicides (Weber, Entrop, 2017). Therefore, identification and characterization of the causal agents of chocolate spot disease are important, because species have different optimal conditions of development and sensitivities to fungicide, so the spectrum of pathogens is likely to affect the efficacy of disease control (Fan et al., 2015).

The aim of this study was to determine the range of Botrytis species that could be recovered from faba bean, evaluate their morphological diversity in vitro and determine their pathogenicity by a leaf inoculation test.

\section{Materials and methods}

Sample collection and fungal isolation. Faba bean leaves, pods and seeds with symptoms of chocolate spot disease were collected during the growing seasons of 2014, 2015 and 2016 at the Pêterlauki Research and Study Farm $\left(56.54^{\circ} \mathrm{N}, 23.71^{\circ} \mathrm{E}\right)$ of the Latvia University of Life Sciences and Technologies (Table 1).

Small pieces of the infected plant tissues (edges of necrotic lesions) were surface sterilized with $1 \% \mathrm{NaClO}$ (sodium hypochlorite) for $1 \mathrm{~min}$, rinsed three times in sterile distilled water and placed on potato dextrose agar (PDA) with $0.1 \mathrm{mg} \mathrm{L}^{-1}$ streptomycin and $0.1 \mathrm{mg} \mathrm{L}^{-1}$ penicillin. Cultures were incubated for one week at $20^{\circ} \mathrm{C}$ under 12/12 h light/darkness with 10000 lux illumination. The same temperature and light regime were used during all series of the experiment. Isolates from each colony of suspected Botrytis spp. were obtained by sub-cultivation of hyphal tips on PDA (Leyronas et al., 2012).

Each monoculture's isolate that had morphological characteristics corresponding to Botrytis spp. (Table 1) was multiplied for further investigation. Two additional isolates, one from pea seeds and one from wheat roots, were added to the collection. By transferring mycelial plugs $(5 \mathrm{~mm} \varnothing)$ from the margins of a one-

Table 1. Botrytis spp. isolates, the host organ from which they were isolated and the year of isolation

\begin{tabular}{|c|c|c|c|c|c|c|}
\hline Isolate & $\begin{array}{c}\text { Year of } \\
\text { isolation }\end{array}$ & $\begin{array}{c}\text { Organ of } \\
\text { host }\end{array}$ & No. & Isolate & $\begin{array}{c}\text { Year of } \\
\text { isolation }\end{array}$ & $\begin{array}{c}\text { Organ of } \\
\text { host }\end{array}$ \\
\hline PL3-1 & 2014 & leaves & 23 & 16PGF13 & 2016 & seeds \\
\hline 18B7-1 & 2014 & leaves & 24 & 16PGF23 & 2016 & seeds \\
\hline 17B10-1 & 2014 & leaves & 25 & 16PGF23-2 & 2016 & seeds \\
\hline 15PG2 & 2015 & seeds & 26 & 16PGF23-2-1 & 2016 & seeds \\
\hline $18 \mathrm{~B} 8$ & 2015 & seeds & 27 & 17B21 & 2016 & seeds \\
\hline B9 & 2016 & leaves & 28 & 17B22 & 2016 & seeds \\
\hline B11 & 2016 & leaves & 29 & $18 \mathrm{~B} 2-2$ & 2016 & seeds \\
\hline $17 \mathrm{~B} 3$ & 2016 & leaves & 30 & $17 \mathrm{~B} 23$ & 2016 & seeds \\
\hline $17 \mathrm{~B} 4$ & 2016 & leaves & 31 & $17 \mathrm{~B} 24$ & 2016 & seeds \\
\hline $17 \mathrm{~B} 8$ & 2016 & leaves & 32 & $17 \mathrm{~B} 25$ & 2016 & seeds \\
\hline 18B12-3 & 2016 & leaves & 33 & $17 \mathrm{~B} 27$ & 2016 & seeds \\
\hline $17 \mathrm{~B} 28$ & 2016 & leaves & 34 & $17 \mathrm{~F} 4$ & 2016 & seeds \\
\hline $17 \mathrm{~F} 2$ & 2016 & leaves & 35 & $17 \mathrm{~F} 9$ & 2016 & seeds \\
\hline $17 \mathrm{~F} 3$ & 2016 & leaves & 36 & 18B1 & 2016 & seeds \\
\hline $17 \mathrm{~F} 14$ & 2016 & leaves & 37 & 18B1-1 & 2016 & seeds \\
\hline 18B4 & 2016 & leaves & 38 & $18 \mathrm{~B} 2-2-1$ & 2016 & seeds \\
\hline $18 \mathrm{~B} 5-2$ & 2016 & leaves & 39 & 18B2-3 & 2016 & seeds \\
\hline 18B5-2-1 & 2016 & leaves & 40 & 18B3 & 2016 & seeds \\
\hline 18B5-3 & 2016 & leaves & 41 & $18 \mathrm{~B} 11$ & 2016 & seeds \\
\hline 18B6 & 2016 & leaves & 42 & $18 \mathrm{~B} 16$ & 2016 & seeds \\
\hline 16PG3 & 2016 & seeds & 43 & $16 \mathrm{~J} 15$ & 2015 & seeds, peas \\
\hline 16PG48-1 & 2016 & seeds & 44 & 17PS24 & 2017 & stem base, wheat \\
\hline
\end{tabular}

week-old culture, 9 working cultures for each isolate were established: 4 for morphological characterization, 4 for the pathogenicity test and 1 for molecular-genetic analysis.

Molecular-genetic analysis. DNA was extracted by suspending $\sim 10 \mu \mathrm{g}$ of fungal material in NucleoMag $\mathbb{R}$ 96 Plant kit (Macherey-Nagel, Germany) lysis buffer, homogenizing for $2 \times 60 \mathrm{sec}$ using FastPrep ${ }^{\circledR}-24$ instrument and Lysing Matrix D (MP Biomedicals, USA), phenol (Alfa Aesar, Germany) and chloroform (Merck, USA) treatment and subsequently using the NucleoMag ${ }^{\circledR} 96$ Plant kit according to the manufacturer's instructions.

The Botrytis isolates were identified at the species level by sequencing the RNA polymerase II gene (RPB2), heat shock protein 60 (HSP60) and glyceraldehyde 3phosphate dehydrogenase $(G 3 P D H)$ genes fusing of acquired DNA sequences and subsequent phylogenetic clustering. The primers (Table 2 ) followed those used by Staats et al. (2005)

The PCR amplification of RPB2, HSP60 and $G 3 P D H$ genes was carried out for 40 cycles $\left(98^{\circ} \mathrm{C}\right.$ for 5 sec, $59^{\circ} \mathrm{C}$ for $5 \mathrm{sec}$ and $72^{\circ} \mathrm{C}$ for $20 \mathrm{sec}$ ) in a GeneAmp
PCR System 9700 (Applied Biosystems, USA). The reaction mixture was comprised of $10 \mu \mathrm{l}$ of H2X Phire Plant Direct PCR Master Mix (Thermo Fisher Scientific, USA), $0.3 \mu \mathrm{M}$ forward primer and $0.3 \mu \mathrm{M}$ reverse primer and $1 \mu \mathrm{l}$ of fungal DNA with Rnase-free water to make a total volume of $20 \mu \mathrm{l}$. The success of the amplification was verified through the inspection of PCR products by $1.5 \%$ agarose gel electrophoresis. Samples were considered positive, when they contained a PCR fragment $>700 \mathrm{bp}$.

Positive reaction mixtures were cleaned up from excess of dNTPs and primers through the employment of $0.5 \mu \mathrm{l}$ Exonuclease I and $2 \mu \mathrm{l}$ Shrimp Alkaline Phosphatase (Thermo Fisher Scientific), incubated for $40 \mathrm{~min}$ at $37^{\circ} \mathrm{C}$ and inactivated at $95^{\circ} \mathrm{C}$ for $20 \mathrm{~min}$. A $1 \mu \mathrm{l}$ aliquot of cleaned fragment solution was transferred to BigDye ${ }^{\circledR}$ Terminator v3.1 Cycle Sequencing reaction mixture that had been prepared according to the manufacturer's (Applied Biosystems) instructions. Both DNA strands of every PCR product were sequenced, and sequencing products were analysed on a 3130xl Genetic Analyzer (Applied Biosystems).

For reference, the RPB2, HSP60 and G3PDH sequences of $B$. byssoidea, $B$. calthae, B. convoluta, 
Table 2. Primers for PCR amplification and sequencing

\begin{tabular}{clcc}
\hline & \multicolumn{2}{c}{ Forward primer } & Reverse primer \\
\cline { 2 - 4 } Gene & $\begin{array}{c}\text { sequence } \\
\text { length nt }\end{array}$ & sequence \\
\hline G3PDH & 5'-ATTGACATCGTCGCTGTCAACGA-3' & 23 & 5'-ACCCCACTCGTTGTCGTACCA-3' \\
HSP60 & 5'-CAACAATTGAGATTTGCCCACAAG-3' & 24 & 5'-GATGGATCCAGTGGTACCGAGCAT-3' \\
RPB2 & 5'-GATGATCGTGATCATTTCGG-3' & 20 & 5'-CCCATAGCTTGCTTACCCAT-3' \\
\hline
\end{tabular}

B. croci, B. elliptica, B. fabae, B. ficariarum, B. fuckeliana, B. galanthina, B. gladiolorum, B. globosa, $B$. hyacinthi, B. narcissicola, B. paeoniae, B. pelargonii, $B$. polyblastis, $B$. porri, $B$. sphaerosperma, $B$. squamosa, B. aclada, B. allii, B. californica, B. cinerea, B. eucalypti, $B$. fabiopsis, $B$. prunorum, $B$. pseudocinerea, $B$. ranunculi, $B$. sinoallii, $B$. sinoviticola and $B$. tulipae along with outgroup members Amphobotrys ricini, Monilinia fructigena and Sclerotinia sclerotiorum were downloaded from the NCBI nucleotide database (Staats et al., 2005). The sequences were aligned by program Clustal $W$, version 2.0 (Larkin et al., 2007), alignments were trimmed by software trimAl employing the strict method (Capella-Gutiérrez et al., 2009), and the results were clustered by software MEGA5 employing the neighbour-joining algorithm to give a phylogenetic tree (Tamura et al., 2011).

Morphological characterization. To evaluate morphological traits, cultures were incubated at $20^{\circ} \mathrm{C}$ in the dark for one week, and characterisation was performed according to observed traits of cultures (Table 3). Colour and structure of mycelium and pigmentation of media were evaluated 14 days after resowing of hyphae tips. The size and location of sclerotia were evaluated 21 days after resowing, and isolates with similar descriptions were grouped. After performing molecular-genetic analysis, isolates that were identified as B. fabae were compared to reference isolate EX-B18-0701 obtained from Westerdijk Fungal Biodiversity Institute, The Netherlands.

Pathogenicity test. Pathogenicity was tested in vitro. In a pathogenicity test, 44 isolates were tested. Leaves were obtained from the middle levels of glasshouse-grown faba bean cultivar 'Fuego' plants at $\mathrm{BBCH}$ growth stage 35 (5 visibly extended internodes) and rinsed twice with sterile water. Sheets of sterile filter paper were cut to the size of the tray base $(40 \times 30 \times$ $5 \mathrm{~cm}$ ) and lined in two layers in metal trays. To support the leaves, eight $28 \mathrm{~cm}$ long glass sticks were arranged into each tray. The leaves were placed so that only the petiole touched the filter paper. An equal amount of water $75 \mathrm{ml}$ was poured into each tray so that it was moist, but the water did not accumulate in puddles. Each tray contained 30 leaves with two leaflets. Agar plugs with Botrytis isolates were placed on leaflets with the mycelium side down; as a control, two non-inoculated agar plugs were used. After inoculation, the trays were covered with plastic film to maintain high humidity and incubated at $20^{\circ} \mathrm{C}$ in the dark for $72 \mathrm{~h}$. The diameter of the lesion formed under the inoculated plug was determined and used as the measure of isolate virulence. Pathogenicity assessments were made in four replicates, one leaflet - one replicate.

Table 3. Morphological criteria used to characterize Botrytis isolates

\begin{tabular}{|c|c|c|}
\hline Characteristic & Variation & Score \\
\hline Colour of mycelium & $\begin{array}{l}\text { white } \\
\text { greyish-white } \\
\text { greyish brown } \\
\text { grey }\end{array}$ & $\begin{array}{l}1 \\
2 \\
3 \\
4\end{array}$ \\
\hline Texture of mycelium & $\begin{array}{l}\text { flat } \\
\text { tufted } \\
\text { cottony } \\
\text { powdered }\end{array}$ & $\begin{array}{l}1 \\
2 \\
3 \\
4\end{array}$ \\
\hline Mode of growing & $\begin{array}{l}\text { regular } \\
\text { radiate } \\
\text { lobate }\end{array}$ & $\begin{array}{l}1 \\
2 \\
3\end{array}$ \\
\hline Pigmentation of media & $\begin{array}{l}\text { no colouring } \\
\text { yellow } \\
\text { brown } \\
\text { brownish-yellow }\end{array}$ & $\begin{array}{l}1 \\
2 \\
3 \\
4\end{array}$ \\
\hline $\begin{array}{l}\text { Size and arrangement } \\
\text { of sclerotia }\end{array}$ & $\begin{array}{l}\text { no sclerotia } \\
\text { large }(>4 \mathrm{~mm}) \text {, few } \\
\text { small }(\leq 4 \mathrm{~mm}) \text {, scattered } \\
\text { large }(>4 \mathrm{~mm}) \text {, scattered } \\
\text { large }(>4 \mathrm{~mm}) \text {, concentric circles along the edges }\end{array}$ & $\begin{array}{l}1 \\
2 \\
3 \\
4 \\
5\end{array}$ \\
\hline
\end{tabular}

Statistical analysis. To evaluate the diameter of lesions caused by artificial infection with Botrytis spp. depending on Botrytis species, one-way analysis of variance (ANOVA) was used with software $R$, version 3.6.2 (R Core Team). The differences among species were compared using the Bonferroni test with an $\alpha=0.05$.

\section{Results}

Molecular-genetic analysis. The evolutionary relationships among the 44 isolates collected in Latvia and isolates from GenBank showing in the phylogenetic tree, genus Botrytis formed a clade with $99 \%$ bootstrap support, distinct from closely related $M$. fructigena and $S$. sclerotiorum outgroups. Branches under $50 \%$ bootstrap support were not included in the phylogenetic tree. The phylogenetic analysis confirmed that all 44 isolates were Botrytis spp.: 8 as B. fabae, 12 as B. cinerea, 5 as B. fabiopsis and 19 as B. pseudocinerea. There were two distinct clades within the genus: I - including $B$. cinerea, $B$. fabae and B. pseudocinerea, and II - containing B. fabiopsis. Clade I was divided into two separated groups with $100 \%$ bootstrap support, of which the larger group I consisted of $18 \mathrm{~B}$. pseudocinerea isolates and the smaller group II comprised $B$. cinerea and $B$. fabae. One of the clusters within the $B$. pseudocinerea group consisted of isolates 16PGF23, 16PGF23-2 and 16PGF23-2-1 that were isolated during purification and had different phenotypic characteristics (Figure 1). 


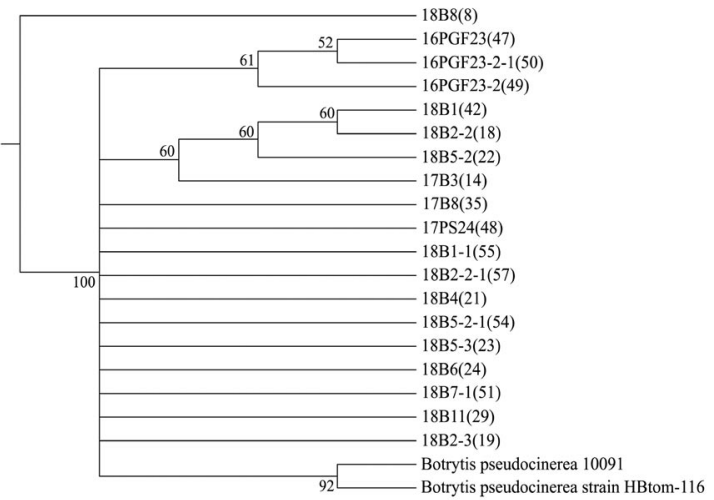

Figure 1. Phylogenetic tree of genetic distances between isolates of Botrytis pseudocinerea

Eight isolates were grouped with $B$. fabae with a strong bootstrap value (Figure 2). Isolates 16PGF13 and $17 \mathrm{~B} 4$ separated from $17 \mathrm{~F} 3$ with a strongly supported node ( $92 \%$ bootstrap).

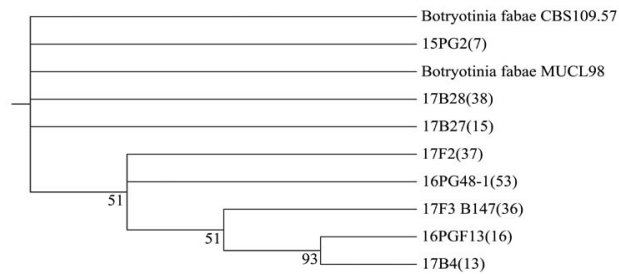

Figure 2. Phylogenetic tree of genetic distances between isolates of Botrytis fabae

A high genetic differentiation was observed within $B$. cinerea. Isolate $18 \mathrm{~B} 3$ was separated from the other 11 isolates grouped into three clusters with bootstrap support $53-71 \%$ (Figure 3).

Five isolates were clearly grouped with B. fabiopsis, and of the isolates analysed during the experiment were the only representatives of Clade II (Figure 4).

Morphological characterization. The 8 isolates of $B$. fabae formed three morphotypes (Figure 5A). The mycelium was white to greyish white, flat or cottony, the medium was not colouring or brown, the mode of a colony growing was regular or radiate. Part of the isolates did not form sclerotia in some cases, and sclerotia were small and scattered. None of the isolates corresponded

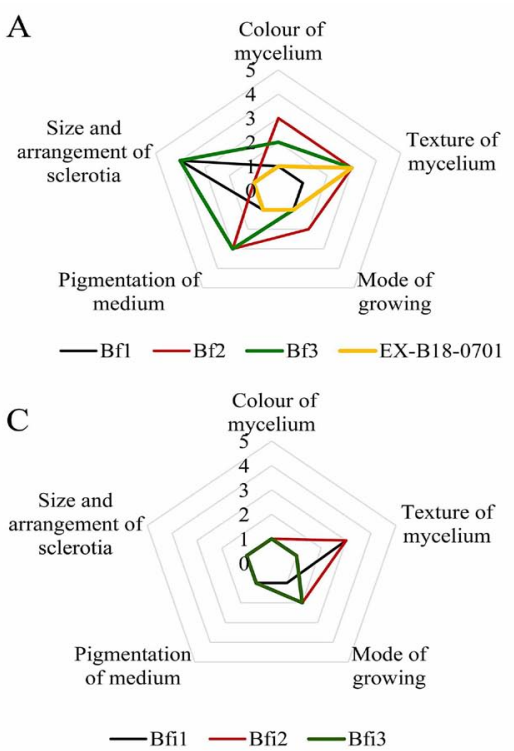

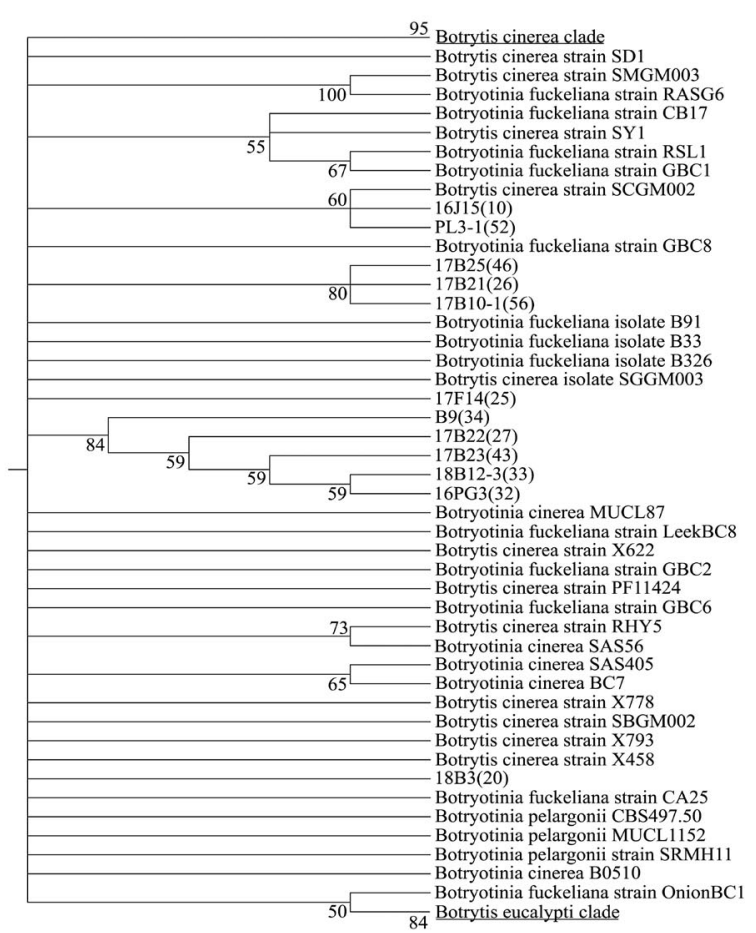

Figure 3. Phylogenetic tree of genetic distances between isolates of Botrytis cinerea

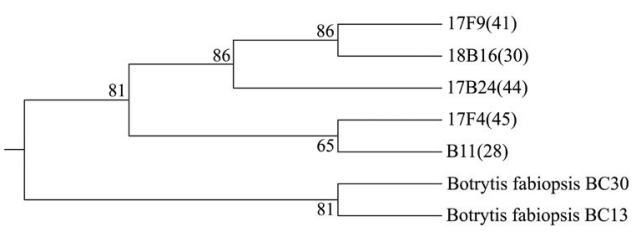

Figure 4. Phylogenetic tree of genetic distances between isolates of Botrytis fabiopsis

in morphology to the reference $B$. fabae isolate EX$\mathrm{B} 18-0701$. The 12 isolates of $B$. cinerea formed six morphotypes (Figure 5B), and their morphological traits varied widely. All possible colours, textures and growing modes of mycelium were found. Medium mostly was colourless, only some isolates coloured medium in brownish-yellow. Sclerotia were not formed or were few, large and scattered. The 5 isolates of B. fabiopsis were

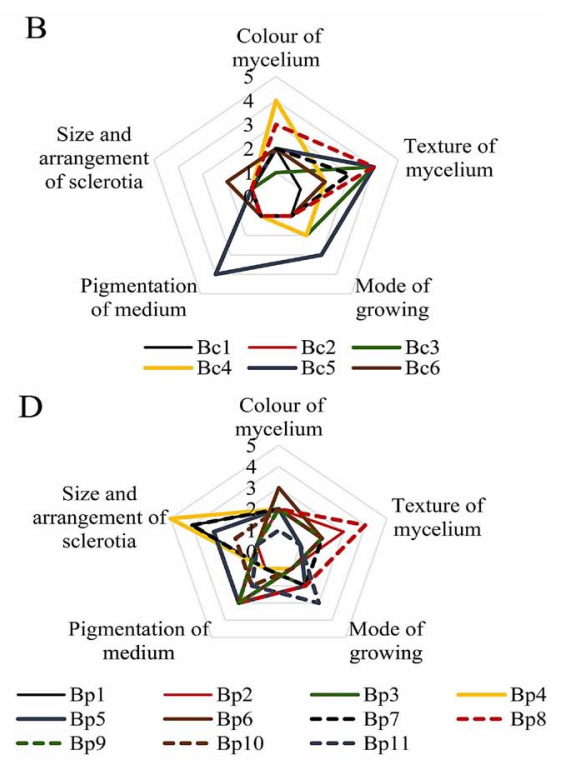

Figure 5. Radar plots showing morphological characteristics of Botrytis isolate groups: B. fabae (A), B. cinerea (B), B. fabiopsis (C) and B. pseudocinerea (D) 
relatively similar, all had white to greyish white mycelium and none formed sclerotia or coloured the medium. The only differences observed were mycelium texture (cottony or flat) and mode of growing (regular or radiate). Three different morphotypes were determined (Figure 5C). The widest variation was observed in the largest group, namely the B. pseudocinerea isolates. Almost all possible variants of the five traits were observed, the exceptions being that there was no grey mycelium and no brownish-yellow colouring of the medium. Eleven morphotypes were observed (Figure 5D).

Pathogenicity test. The first symptoms of Botrytis spp. infection on faba bean leaves were visible 24 $\mathrm{h}$ after inoculation. Lesion size differed $(p<0.01)$ between the species $48 \mathrm{~h}$ after inoculation (Figure 6). B. fabae caused the largest necrotic lesions $(18.5 \mathrm{~mm})$, followed by B. pseudocinerea $(16.3 \mathrm{~mm})$ and $B$. cinerea $(14.6 \mathrm{~mm})$, but lesions caused by $B$. fabiopsis were significantly smaller $(4.0 \mathrm{~mm})$. Five isolates: B. cinerea $18 \mathrm{~B} 3$, B. fabiopsis $17 \mathrm{~F} 4$ and B11, and B. pseudocinerea 18B2-2 and 18B6, of three species did not cause infection symptoms. Control leaves with uninoculated agar plugs remained healthy.

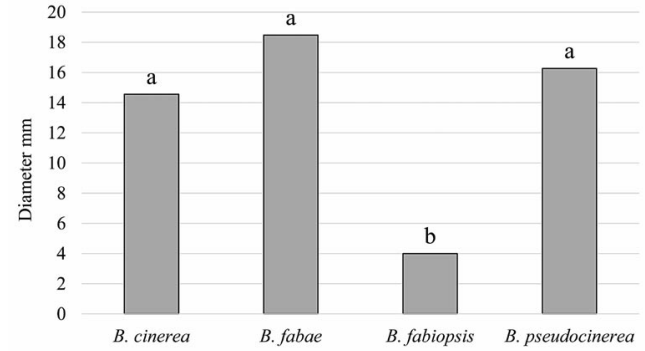

Note. Different letters indicate the significance $(p<0.01)$ of the difference between the species.

Figure 6. Diameter of necrotic lesions on faba bean leaves caused by Botrytis spp. during pathogenicity test in vitro

\section{Discussion}

Presented results show that four species of Botrytis can be isolated from faba bean parts showing symptoms of chocolate spot disease and that all of them can cause disease symptoms in detached leaves. Thus, previous findings were confirmed that chocolate spot could be caused not only by $B$. fabae and $B$. cinerea but also by $B$. fabiopsis (Zhang et al., 2010) and B. pseudocinerea (Plesken et al., 2015; Bankina et al., 2017) and uniquely demonstrated that all four species could be found in northern Europe. Furthermore, all four species have been found in Latvia with the most recent discovery of B. pseudocinerea (Bankina et al., 2017). Thus, the traditional assignment of chocolate spot disease to $B$. fabae alone is not appropriate.

In the present study, to identify the species level, sequence information from three nuclear DNA genes (G3PDH, HSP60 and RPB2) was used. For this purpose, these have been recognized as the most informative loci (Staats et al., 2005). Morphological characteristics alone are not sufficient to distinguish species of Botrytis. The genus is known to be characterized by enormous morphological and genetic diversity within species and phylogenetic clades (Garfinkel et al., 2019).

In vitro, each of the four species showed considerable morphological diversity and could be divided into several morphotypes. Notably, no morphotype was found in the two species, but there was considerable overlap with different morphotypes sharing up to four of the five traits that were evaluated. Similarly, consistent morphological differences were not found between $B$. cinerea and $B$. pseudocinerea in cultures in Hungary (Fekete et al., 2012) or France (Walker et al., 2011). Thus, diversity of morphological characteristics may be related to other aspects of the pathogen's genetic variability that were not detected in the three genes used here. The high morphological diversity of $B$. cinerea and $B$. pseudocinerea isolates has been described by several authors (Lorenzini, Zapparoli, 2014; Acosta Morel et al., 2019).

In all cases, the molecular genotyping provided unequivocal identification of the species of each isolate. The clustering followed expectations from the literature with $B$. fabae and $B$. cinerea as the most closely related pair, then $B$. pseudocinerea one step away and $B$. fabiopsis remote from the other three. The separation of $B$. pseudocinerea from $B$. cinerea was established by Fournier et al. (2005), who suggested that group I and group II of $B$. cinerea were true phylogenetic species, and confirmed by Walker et al. (2011), who separated $B$. pseudocinerea as the new species from group I. Both $B$. cinerea and $B$. pseudocinerea have wide host ranges including orchard fruits along with faba bean and oilseed rape, and the ratio between them may be influenced by the usage of fungicides on the crops (Plesken et al., 2015; Weber, Entrop, 2017). However, the relative importance of the two species differs: $B$. pseudocinerea dominating on several crop species in Germany (Plesken et al., 2015) but rare on grapevine in Spain (Acosta Morel et al., 2019). Presented results confirmed the potential significance of $B$. pseudocinerea as the causal agent of chocolate spot disease, because about $43 \%$ of isolates were identified as B. pseudocinerea.

Although $B$. fabae is phylogenetically very close to $B$. cinerea, as previously found (Walker et al., 2011), it is widely considered host-specific to $V$. faba. In culture, the species are often indistinguishable (Lee et al., 2020). Some Chinese $B$. cinerea isolates were more virulent on faba bean leaves than $B$. fabae (Zhang et al., 2010).

B. fabiopsis is also considered to be hostspecific to faba bean, but its wide separation from these other three species was noted by its discoverers (Zhang et al., 2010). Its low pathogenicity was notable here and contrasts with the result of Zhang et al. (2010), where one of three $B$. fabiopsis isolates was as virulent on faba bean leaves as $B$. fabae. In the phylogenetic tree, the $B$. fabiopsis isolates used in the experiment and isolates from China formed closely related but distinct clades.

\section{Conclusions}

1. Chocolate spot disease on faba bean is caused by at least Botrytis four species: B. fabae, B. cinerea, $B$. fabiopsis and $B$. pseudocinerea, not just the one to which it is usually attributed.

2. Each of the species showed considerable morphological diversity and could be divided into several morphotypes. To distinguish these closely related pathogens from each other, morphological phenotyping is not enough; instead, molecular genotyping at the DNA (or possibly RNA) level is necessary.

3. All four species are pathogens of faba bean, but the virulence of $B$. fabiopsis is significantly lower compared to other species.

4. The knowledge of the diversity of pathogens may help search for effective host resistance pathways in the future.

\section{Acknowledgements}

This research was funded by the Latvian Council of Science project "Pathogenicity and diversity of Botrytis spp. - important causal agents of legume diseases", project No. lzp-2019/1-0034.

Received 20072021

Accepted 23092021

\section{References}

Acosta Morel W., Marques-Costa T. M., Santander-Gordón D., Anta Fernández F., Zabalgogeazcoa I., Vázquez de Aldana B. R., Sukno S. A., Díaz-Mínguez J. M., Benito E. P. 2019. Physiological and population genetic analysis of Botrytis field isolates from vineyards in Castilla y León, Spain. Plant Pathology 68 (3). 523-536

https://doi.org/10.1111/ppa.12967 
Bankina B., Bimšteine G., Neusa-Luca I., Roga A., Fridmanis D. 2017. Less known species of Botrytis spp. - the causal agents of faba bean chocolate spot. XX Symposium of Baltic Mycologists and Lichenologists: book of abstracts. Gdansk, Poland p. 27.

Bankina B., Bimšteine G., Kaņeps J., Plūduma-Pauniña I. Gaile Z., Paura L., Stoddard F.' L. 2021. Discrimination of leaf diseases affecting faba bean (Vicia faba). Acta Agriculturae Scandinavica, Section B: Soil and Plant Science, 71 (5): 399-407. https://doi.org/10.1080/09064710.2021.1903985

Bilkiss M., Shiddiky M. J.A., Ford K. 2U1Y. Advanced diagnostic approaches for necrotrophic fungal pathogens of temperate legumes with a focus on Rotry)tis snn. Frontiers in Microbiology, 1: 1889. https://doi.org/10.3389/fmicb.2019.01889

Brauna-Morżevska E., Bankina B., Kaṇeps J. 2019. Botrytis genus fungi as causal agents of legume diseases: a review. Proceedings of $25^{\text {th }}$ international scientific conference Research for Rurral Develonment 2019 , vol. 2, p. 63-69. https://doi.org/10.22616/rrd.25.2019.050

Capeilia-Gutierrez S., Silïa-M̄artinez J. M̀., Gabaldón T. 2009. trimAl: a tool for automated alignment trimming in largescale phylogenetic analyses. Rininformatics, $25(15) \cdot 1972$ 1973. https://doi.org/10.1093/bioinformatics/btp348

Coca-Morante M., Mamani-Álvarez F. 2012. Control of leaf spot diseases on ecotypes of faba bean (Vicia faba L.) produced in the Andean Region of Bolivia. American Journal of Plant Sciences, 3 (8): 1150-1158.

https://doi.org/10.4236/ajps.2012.38139

Elad Y., Pertot 1., Cotes Prado A. M., Stewart A. 2016. Plant hosts of Botrytis spp. Fillinger S., Elad Y. (eds). Botrytis - the Fungus, the Pathogen and its Management in A gricultural Systems. Snringer, n. 413-486. https://doi.org/10.1007/978-3-319-23371-0 20

Eurostat. 2021 . Dry pulses and protein crops for the production of grain (including seed and mixtures of cereals and nulses) hy area, nroduction and humidity httnc //ec eurnna eul eurostat/databrowser/view/tag00094/default/table\%lang=en

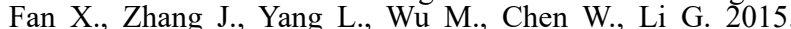
Development of PCR-based assays for detecting and differentiating three species of Botrytis infecting broad hean Plant Dicease $90(5) \cdot 601-608$ https://doi.org/10.1094/PDIS-07-14-0701-RE

Fekete E., rekete E., Irinyi L., Karafta L., Árnyasi M., Asadollahi M., Sándor E. 2012. Genetic diversity of a Botrytis cinerea cryptic species complex in Hungary. Mirrohinlogical Recearch 167 (5). 283-291. https://doi.org/10.1016/j.micres.2011.10.006

Fournier E., Giraud 1., Albertini C., Brygoo Y. 2005. Partition of the Botrytis cinerea complex in France using multiple gene genealogies. Mycologia, 97 (6): 1251-1267. https://doi.org/10.1080/15572536.2006.11832734

Gartinkel A. K., Coats K. P., Sherry D. L., Chastagner G. A. 2019. Genetic analysis reveals unprecedented diversity of a globally-important nlant nathogenic genus. Scientific Renorts, 9 (1): 13-19. https://doi.org/10.1038/s41598-019-43165-y
Harrison J. G. 1988. The biology of Botrytis spp. on Vicia beans and chocolate snot disease - a review Plant Patholnov 37 (2): 168-201. https://doi.org/10.1111/j.1365-3059.1988.tb02064.x

Larkin M. A., Blackshieids G., Brown N. P., Chenna K., McGettigan P. A., McWilliam H., Valentin F., Wallace I. M., Wilm A., Lopez R., Thompson J. D., Gibson T. J., Higgins D. G. 2007. Clustal W and Clustal X version 2.0. Bininformatics, 23 (21): 2947-2948 https://doi.org/10.1093/bioinformatics/btm404

Lee K. C., Fartan-Caceres L. M., Debler J. W., Syme R. A. 2020. Characterization of growth morphology and pathology, and draft genome sequencing of Botrytis fabae, the causal organism of chocolate spot of faba bean (Vicia faba L.). Frontiers in Microhiology, 11: 1-19 https://doi.org/10.3389/fmicb.2020.00217

Leyronas C., Dutfaud M., Nicot P. C.'201'2. Compared efficiency of the isolation methods for Rntm,tic sineren Mvonlogy, 3 (4): 221-225. https://doi.org/10.1080/21501203.2012.727484

Lorenzini M., Zapparoli G. 2U14. An isolate morphologically and phylogenetically distinct from Botrytis cinerea obtained from withered grapes possibly represents a new species of Rntri,tis. Plant Pathology, 63 (6): 1326-1335. https://doi.org/10.1111/ppa.12216

Plesken C., Weber K. W. S., Kupp S., Leroch M., Hahn M. 2015. Botrytis pseudocinerea is a significant pathogen of several crop plants but susceptible to displacement by fungicide-resistant B. cinerea strains. Annlied and Environmental Microbiolooy, 81 (20): 7048-7056. https://doi.org/10.1128/AEM.01719-15

Staats M., van Baarlen P., van Kan J. A. L. 2UUJ. Molecular phylogeny of the plant pathogenic genus Botrytis and the evolution of host snecificity Molecular Rinloov and Fvolution, 22 (2): 333-346. https://doi.org $/ 10.1093 / \mathrm{molbev} / \mathrm{msi0} 20$

Stoddard F. L., Nicholas A. H., Kubiales D., I homas J., VillegasFernández A. M. 2010. Integrated pest management in faba hean Field Crons Research 115 (3) : 308-318. https://doi.org/10.1016/j.fcr.2009.07.002

Tamura K., Peterson D., Peterson N., Stecher G., Nei M., Kumar S. 2011. MEGA5: molecular evolutionary genetics analysis using maximum likelihood, evolutionary distance, and maximum parsimony methods. Molecular Biology and Fvolution 28 (10): 2731-2730 https://doi.org/10.1093/molbev/msr121

Walker A.-S., Gautier A., Confais J., Martinho D., Viaud M., Le Pêcheur P., Dupont J., Fournier E. 2011. Botrytis pseudocinerea, a new cryptic species causing gray mold in French vineyards in sympatry with Rotw)tic cineron. Phvtonathology 101 (12): 1433-1445. https://doi.org/10.1094/PHYTO-04-11-0104

Weber R. W. S., Entrop A. P. 201\% Kecovery of fungicideresistant Botrytis isolates from strawberry nursery plants. Euronean Iournal of Plant Pathology, 149: 739-742. https://doi.org/10.1007/s10658-017-1206-9

Zhang J., Wu M. De, Li G. U., Yang L., Yu L., Jiang D. H., Huang H. C., Zhuang W. Y. 2010. Botrytis fabiopsis, a new species causing chocolate spot of hroad hean in central China. Mycologia, 102 (5): 1114-1126. https://doi.org/10.3852/09-217

\title{
Pupų rudajją dėmėtligę Latvijoje sukelia keturios grybo Botrytis rūšys
}

\author{
B. Bankina ${ }^{1}$, F. L. Stoddard ${ }^{2}$, J. Kaṇeps ${ }^{1}$, E. Brauna-Morževska ${ }^{1}$, G. Bimšteine ${ }^{1}$, \\ I. Neusa-Luca ${ }^{1}$, A. Roga ${ }^{3}$, D. Fridmanis ${ }^{3}$
}

${ }^{1}$ Latvijos gyvybės mokslų ir technologijų universiteto Dirvožemio ir augalų mokslų institutas

${ }^{2}$ Helsinkio universiteto Žemès ūkio mokslų departamentas, Suomija

${ }^{3}$ Latvijos biomedicininių tyrimų ir studijų centras

\section{Santrauka}

Pupos (Vicia faba L.) tampa vis svarbesniais augalais Šiaurès Europoje. Šiame regione plačiausiai paplitusi pupu liga yra rudoji (šokoladinė) dèmètligè, kurią sukelia patogenas Botrytis fabae. Tyrimo metu Latvijoje nustatyta, kad ligą sukelia ir kitos Botrytis spp. rūšys, todęl nuspręsta išskirti patogenus iš rudosios dèmètligès simptomus turinčių pupų, o Botrytis spp. rūšis identifikuoti pagal trijų determinuojančių genų DNR sekas, ịvertinti izoliatų morfologinę įvairovę in vitro ir nustatyti ju patogeniškumą ant pupų lapų. Be B. fabae, buvo identifikuotos B.cinerea, B. pseudocinerea ir $B$. fabiopsis rūšys. Atlikus DNR seku filogenetinę analizę, visi išskirti 44 izoliatai pagal rūšis pasiskirstė i atskiras grupes. Visos rūšys in vitro pasižyméjo didele spalvos, tekstūros ir micelio augimo, skleročiu bei mitybinès terpès pigmentacijos ivvairove ir dideliu tapatumu tarp rūšiu; tai ịrodo, kad šis metodas nèra tinkamas rūšsims atskirti. Ant lapu didžiausi pažeidimai buvo B. fabae, mažesni - B. pseudocinerea ir B. cinerea, dar mažesni - B. fabiopsis.

Tyrimo rezultatai rodo, kad Siaurès Europoje pupų rudają dėmètligę sukelia keturios Botrytis spp. rūšys. Jie yra svarbūs, siekiant ligą kontroliuoti genetinėmis arba agronominėmis priemonėmis.

Reikšminiai žodžiai: Botrytis cinerea, Botrytis fabae, Botrytis fabiopsis, Botrytis pseudocinerea, filogenetinė analizè, morfologiniai požymiai. 